\title{
Applying a Modified DRASTIC Model to Assess Groundwater Vulnerability to Pollution: A Case Study in Central Poland
}

\author{
Michał Kozłowski ${ }^{1 *}$, Mariusz Sojka ${ }^{2}$ \\ 'Poznań University of Life Sciences, Department of Soil Science and Land Reclamation, Poznań, Poland \\ ${ }^{2}$ Poznań University of Life Sciences, Institute of Land Improvement, Environmental Development, \\ and Geodesy, Poznań, Poland
}

Received: 7 December 2017

Accepted: 24 January 2018

\begin{abstract}
Our paper presents the possibility of applying the DRASTIC model as a useful tool to support the process of local and regional development planning. The study was carried out in the catchment of Stare Miasto Reservoir in Central Poland. In order to plan the policy to protect the reservoir and groundwater, the assessment of groundwater vulnerability to pollution was made by means of the DRASTIC model. The original model was modified by adding a new parameter called "land use." The measured nitrate concentrations were used to test the original and modified models. The results of the study revealed that the modified DRASTIC model gave more accurate predictions than the traditional model. The Pearson correlation coefficients characterising the relationship between the vulnerability index and the nitrate concentration was 0.56 before the modification and 0.69 after it. The groundwater vulnerability map is necessary for planning local development and for assessing environmental impact. The DRASTIC model is expected to be a useful tool for designing programs and strategies, e.g., for improving the quality of surface water and groundwater.
\end{abstract}

Keywords: groundwater vulnerability, DRASTIC model, reservoir

\section{Introduction}

In Poland, since the beginning of the 1990s a dynamic progressive process of urbanization has been observed. Initially, this process concerned mainly the areas adjacent to urbanised areas. Currently, mainly for economic reasons, new locations of development at greater distances from cities have been established.

*e-mail: mkozl@up.poznan.pl
The areas located in the immediate vicinity of the natural and artificial water reservoirs have become of vital interest. Artificial reservoirs are most often located in areas that had been earlier used as agricultural land. After reservoir construction, substantial changes have been observed in the structure of land use. The conversion of arable land to residential, commercial, industrial, and recreational uses is an issue of significant environmental concern. Decisions concerning management of these areas are often made too quickly and without a local development plan, so without taking into account the problems related 
to protecting both surface water and groundwater. Land use changes in areas directly connected to water bodies have a great impact on the ground and surface water contamination [1-4]. One of the most effective methods to protect water against pollution is the proper and efficient use of land located next to the reservoir shoreline. This zone plays a crucial role in reducing pollution loaded to the water bodies [5-6].

Groundwater vulnerability maps have become a worldwide accepted tool in the land use planning process. These maps are designed to identify the areas of greatest potential for groundwater contamination on the basis of hydrogeological conditions. The most widely used groundwater vulnerability mapping method is the empirical model, called DRASTIC. This model is used worldwide because it is easy to use, has minimum data requirements, and gives a clear explanation of groundwater vulnerability [7]. DRASTIC is a multicriteria model based on the hydrogeological factors that control the migration of pollutants into the groundwater. This model uses seven parameters such as: depth to groundwater (D), net recharge potential (R), aquifer media (A), soil media (S), topography (T), impact of vadose zone (I), and hydraulic conductivity $(\mathrm{C})$ of the aquifer.

The concentrations of nitrates and chlorides in the groundwater are used to calibrate the DRASTIC model. The model calibration is carried out by changing the ratings and weights of the parameters [8-10]. Yang et al. [11] have suggested that to improve the calibration process, the total land use in a buffer area around each well should be taken into account. Some authors have used the geostatistical tools to better evaluate the DRASTIC model performance [12].

Many authors have confirmed that the locally conditioned DRASTIC model predicts the aquifer pollution risk more accurately than the original model $[10,13-14]$. The DRASTIC model determines the intrinsic vulnerability and does not take into account the specific vulnerability related to human activities. For this reason, additional models are used that allow assessment of pollution transfer from point and nonpoint sources [15-16].

Many authors have added new parameters that impact groundwater contamination. Most frequently these were the type of land-use [17-20], lineament [21], groundwater velocity [22], and soil exchange capacity [23]. Some authors have excluded some parameters from the original DRASTC model, such as a topography and hydraulic conductivity [24], because these parameters are characterized by low spatial variability over the study area or show strong interdependence. Pacheco and Fernandes [25], on the basis of a multivariate statistical method, have identified strongly correlated parameters that permitted the calculations of groundwater vulnerability to pollution only on the basis of three parameters: topography, recharge, and aquifer material. Many authors have recommended optimizing the DRASTIC model using the analytic hierarchy process (AHP). The AHP method was used for determining the ratings of each parameter in the modified-DRASTIC method [26]. In order to analyse

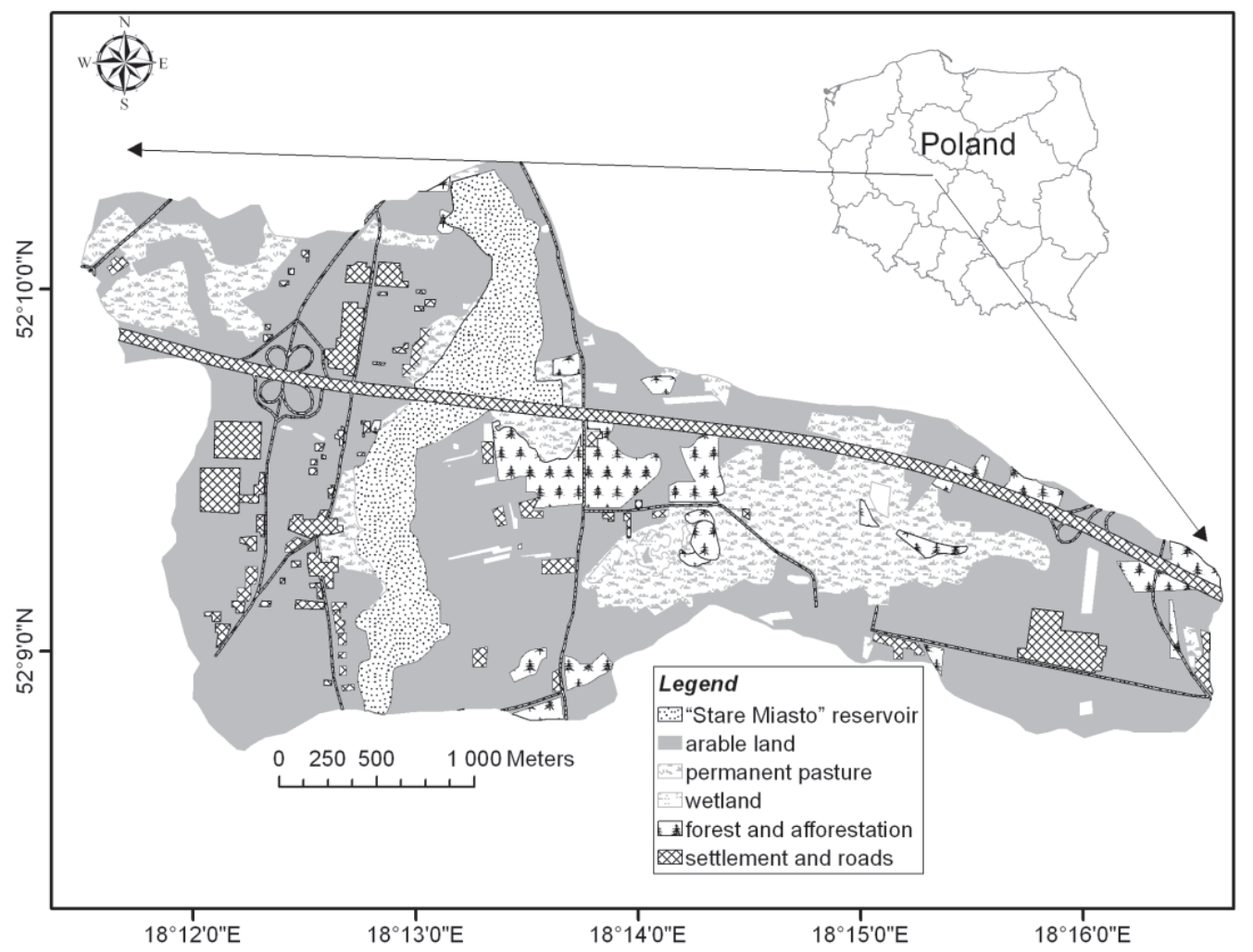

Fig. 1. Study site location. 
Table 1. Rating and weighting values used in the original DRASTIC [7] and modified DRASTIC models.

\begin{tabular}{|c|c|c|c|c|c|}
\hline \multirow{2}{*}{\multicolumn{2}{|c|}{ Factors }} & \multicolumn{2}{c|}{ Original DRASTIC } & \multicolumn{2}{c|}{ Modified DRASTIC } \\
\cline { 2 - 5 } \multicolumn{2}{|c|}{} & Rating & Weight & Rating & Weight \\
\hline D & Depth to groundwater table & $1-10$ & 5 & $1-10$ & 5 \\
\hline R & Net Recharge & $1-9$ & 4 & $1-9$ & 4 \\
\hline A & Aquifer media & $1-10$ & 3 & $1-10$ & 3 \\
\hline S & Soil media & $1-10$ & 2 & $1-10$ & 2 \\
\hline T & Topography & $1-10$ & $1-10$ & $1-10$ \\
\hline I & Impact of vadose zone & $1-10$ & 5 & $1-10$ & 5 \\
\hline C & Hydraulic Conductivity of the aquifer & $1-10$ & 3 & $1-10$ & 3 \\
\hline L & Land use & - & - & & 5 \\
\hline
\end{tabular}

the influence of individual parameters and the results of the DRASTIC method, a sensitivity analysis was performed [27]. Sensitivity analysis provides valuable information on the influence of rating and weights assigned to each parameter and guides decision-makers to assess the significance of subjectivity. Pathak et al. [28] have suggested that more efficient interpretation of the vulnerability index can be achieved by vulnerability analysis.

The original and modified DRASTIC model is particularly suitable for use with geographic information system (GIS) [8, 29-33]. The GIS technique could provide an efficient way to deal with a large quantity of spatial data [19].

The aim of this study was to use a modified DRASTIC model in combination with the geographic information system (GIS) to assess the vulnerability of shallow groundwater to contamination in the catchment of the Stare Miasto Reservoir.

\section{Experimental}

\section{Study Site Description}

The Stare Miasto reservoir is located in the Powa River in central Poland (Fig. 1). The Powa is a thirdorder river and its length is $48.23 \mathrm{~km}$. The entire watershed area of this river is $344.58 \mathrm{~km}^{2}$, in which the Stare Miasto watershed covers $299.7 \mathrm{~km}^{2}$. The Powa River watershed has rural character, where agricultural land takes up to $68.0 \%$ and forested land $27.6 \%$. The proportions of the other land use types are $3.1 \%$ of urban areas, $0.7 \%$ of swamp, and $0.6 \%$ of water. The reservoir was built in 2006 as a multipurpose reservoir designed for flood control, irrigation, recreation, flow augmentation, and hydroelectric power generation. The area of inundation during normal conditions is 90.68 ha and its length is $4.5 \mathrm{~km}$ [34]. The elementary catchment of the Stare Miasto Reservoir covers $9.8 \mathrm{~km}^{2}$. Currently, $75.4 \%$ of the watershed is in agricultural use, most of which is arable land.
The commercial and residential areas occupy $8.9 \%$ and forest only $5.8 \%$. In the basin, groundwater quality is affected negatively by point and nonpoint pollution sources, such as agricultural activities, wastewaters outflows, etc. However, the most important source of pollution is agricultural activity over the catchment area. On the other hand, the proximity of the city of Konin and the A2 Highway make this area attractive for commercial and industrial investment.

\section{Experimental Procedures}

\section{Vulnerability Assessment}

The DRASTIC model was developed by the U.S. Environmental Protection Agency (EPA) to evaluate groundwater pollution potential for the entire United States [7]. The acronym DRASTIC stands for the seven parameters used to calculate the DRASTIC index value: depth to groundwater (D), net recharge (R), aquifer media (A), soil media (S), topography (T), impact of the vadose zone (I), and the hydraulic conductivity of the aquifer (C). Each factor is mainly rated on a scale of 1 to 10 , which indicates the relative pollution potential of a given factor [32] (Table 1). The seven parameters are then assigned with weights ranging from 1 to 5 , reflecting their relative importance (Table 1). The DRASTIC index (DI) or vulnerability rating is then computed by applying a linear combination of all factors:

$$
\begin{aligned}
& D I=D_{r} \cdot D_{w}+R_{r} \cdot R_{w}+A_{r} \cdot A_{w} \\
& +S_{r} \cdot S_{w}+T_{r} \cdot T_{w}+I_{r} \cdot I_{w}+C_{r} \cdot C_{w}
\end{aligned}
$$

...where D, R, A, S, T, I, and C are the seven parameters and the subscripts $r$ and $w$ are the corresponding rating and weights, respectively. The higher the value of DI index, the greater the groundwater vulnerability to pollution.

Several types of data were used to construct thematic layers of the seven model parameters (Fig. 2). 


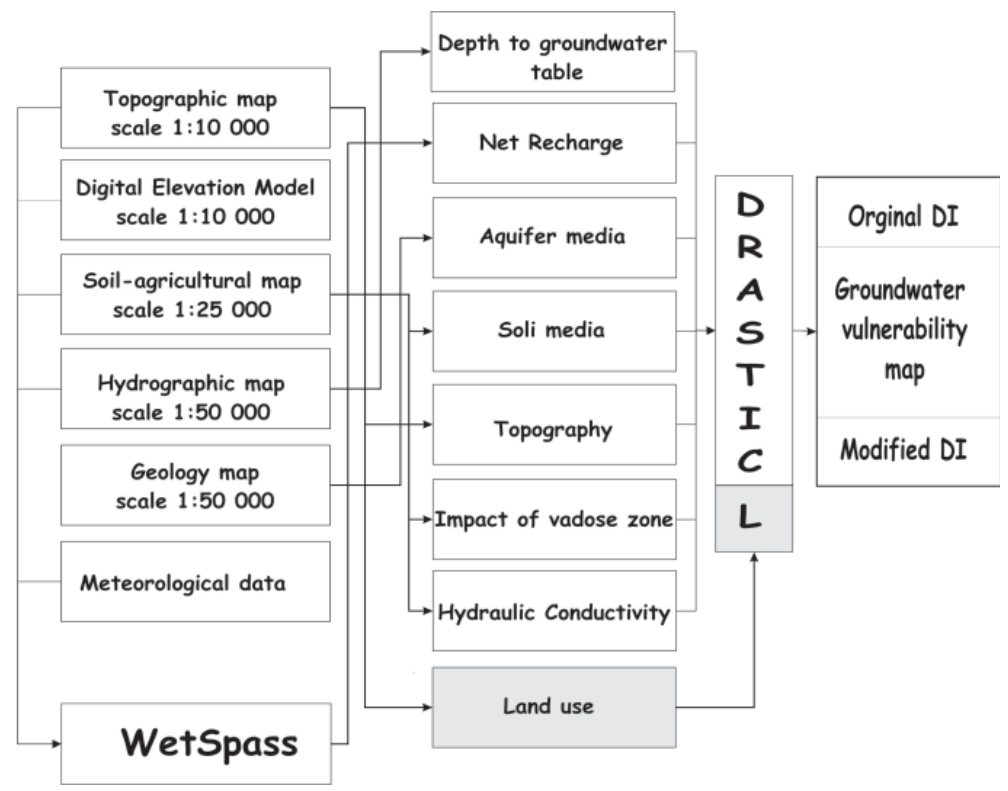

Fig. 2. Flowchart of the methodology.

The data were prepared in GIS format. Commercially available ArcGIS 9.3 software was used to execute the necessary computations. The depth to groundwater table (D) was obtained from hydrographic maps (1:50 000) and 18 groundwater wells. Then, on the basis of these data, the ordinary kriging interpolation was used to create the raster map with a pixel size of $10 \mathrm{~m}$. The depths to groundwater table read from the map were then divided into ranges defined by the original DRASTIC model and they were assigned rates from 1 to 10 . The net recharge $(\mathrm{R})$ represents the amount of water that penetrates the soil surface and reaches the water table. To calculate the net recharge parameter we used the WetSpass model [35]. The meteorological data, land use, slope, soil, and groundwater table depth were used to calculate $\mathrm{R}$ parameter. The obtained values of net recharge were grouped and rated. The Aquifer media (A) refers to the saturated zone material properties, which controls pollution processes. The A factor was obtained using a geological and hydrographic map $(1: 50,000)$ and a soil-agricultural map $(1: 25,000)$. These maps were digitalized to create a representation of different aquifer media units. Then aquifer media units were rated from 2 to 10 . Soil media (S) represents the uppermost weathered portion of the unsaturated zone and controls the amount of recharge that can infiltrate downwards. The soil map was obtained by digitizing the existing soil-agricultural maps. Then the soil texture was assigned with ratings from 1 to 10 . Topography (T) refers in this case to the percentage slope of the land surface, which was determined directly from the Digital Elevation Model (DEM). The slope map was then sliced into ranges and the slopes were assigned ratings ranging from 1 to 10 . The impact of vadose zone (I) on the DRASTIC model is defined as that of the unsaturated zone material. The impact of vadose zone map was obtained using geological, hydrographic $(1: 50,000)$, and soil-agricultural $(1: 25,000)$ maps. These materials allowed us to determine vadose zone sections, which were then encoded in the DRASTIC model rating system. Parameter C (hydraulic Conductivity) indicates the ability of the aquifer to transmit water. The available hydrogeological data [36-38] were analysed to determine the hydraulic conductivity of the aquifer. Different hydraulic conductivity zones in the area were defined and assigned with ratings according to DRASTIC. After creating all the necessary layers, the vulnerability maps were obtained by overlaying the thematic maps in ArcGIS, and the DI was calculated as the weighted sum of the parameters. The DI theoretically ranges from 23 to 226 , small values of DI indicate low vulnerability potential, and high values are related to high pollution potential.

The original DRASTIC model was modified by adding the parameter describing the type of land use, which is important for assessing shallow groundwater vulnerability.

The hazardous chemical species that pollute groundwater include nitrates. These pollutants originate mainly from human and animal wastes as well as from nitrogenous fertilizers. The land use map was prepared to evaluate the groundwater contamination potential. The assumed DRASTIC weight of the land use parameter was 5. The following types of land use were taken into account: wetland, arable land, settlement, permanent pasture, and forest with ratings $10,8,7,5$, and 3, respectively. The values of DI range from 28 to 276 in theory.

The DRASTIC vulnerability index values obtained in the original and modified method were normalized to scale from 0 to 100 . The DI was divided into four categories, namely very low vulnerability $(<38)$, low 
vulnerability (38-50), medium vulnerability (50-63), high vulnerability (63-87), and very high vulnerability (>87).

\section{Sensitivity Analysis}

The impact of the weights of each parameter with their theoretical weights was compared using the singleparameter sensitivity analysis. The effective weight is a function of value of a single parameter with regard to the other parameters as well as the weight assigned to it by the modified-DRASTIC model. The effective weight of each polygon is defined as:

$$
\mathrm{W}=\left(\left(\mathrm{P}_{\mathrm{r}} \times \mathrm{P}_{\mathrm{w}}\right) /: \mathrm{V}\right) \cdot 100
$$

...where $W$ refers to the effective weight of each parameter, $P_{r}$ and $P w$ are the rating value and the weight for each parameter, and $V$ is the overall vulnerability index.

Nitrate concentrations were used to validate both the original DRASTIC and modified DRASTIC methods. A simple linear regression analysis was made to determine the statistical relationship between nitrate concentration and groundwater vulnerability. Two sets of samples, collected in May and August of 2013, were taken from 18 wells, and nitrate concentrations in them were determined. Grubs test showed that there was one outlier value in the data set. One well was located in the waste dump, which could have had a big impact on the final value of Pearson's correlation factor. Finally the analysis was made on the nitrate concentrations in 17 wells.

\section{Results and Discussion}

\section{Assessing Aquifer Vulnerability with the Original DRASTIC Method}

To carry out the shallow groundwater vulnerability assessment using the DRASTIC model, seven factors (Table 1) were used to construct thematic layers in ArcGIS software. The depth to shallow groundwater varies between 0.2 and $4.5 \mathrm{~m}$, therefore the rates range between 9 and 10 (approximately $60 \%$ of the analysed area was rated as 9 and $40 \%$ as 10). The aquifer media in the analysed catchment is mainly composed of permeable sandy sediments. Thus, it has a high permeability rate of 8 (77\% of area). In the rest of the catchment, the aquifer is composed mainly of loam, which is rated at 5. Soil cover of the catchment is variable in terms of taxonomic units. On the basis of interpretation of the content of agricultural-soil maps, Arenosols and Gleysols developed from sandy materials are the dominant soils in the area. Gleysols, Luvisols, and Retisols formed from loam and loamy sand occur in a small area of the catchment. The direct catchment of Stare Miasto Reservoir is situated mainly in the upper and lower terraces, covered in a large proportion with sandy material. Thus, in the areas where the groundwater table is deep, the Arenosols have developed but in areas of shallower groundwater table depth, the Gleysols have developed. These soils are characterized by high water permeability. Depending on the soil texture, the soil media were assigned with ratings of from 6 to 10 . In the catchment area, $79 \%$ of the soils were assigned with a rating of 9 , while $19 \%$ and $2 \%$ of the soils had ratings of 6 and 10, respectively. The topographic layer displayed a gentle slope (0-6\%) over most of the study area (97\%), which has been assigned with the DRASTIC rating scores of 9 and 10. Areas with steep slopes (6-12\%) were typically assigned with a moderate rating score (5), indicating their average effect on groundwater vulnerability. These areas are located in the immediate vicinity of the reservoir, around the eroded edge, occupying an area of approximately $3 \%$. In the impact of vadose zone layer, the sand alluvial deposits $(77 \%$ of area) were assigned with a high rating value (8) and the clay deposits ( $21 \%$ of area) were assigned with the score (3). Generally, the aquifer of direct catchment of Stare Miasto Reservoir is characterized by high hydraulic conductivity, therefore, a great part of the analysed area was assigned with the maximum rating score of 10 .

The DRASTIC vulnerability index values are between 42 and 86 (after normalization). The DRASTIC aquifer vulnerability map clearly shows the dominance of high vulnerability class in the eastern, central, and northwestern parts of the analysed direct catchment (Fig. 3a). These vulnerable zones covered around 77\% of the studied area. The direct catchment of Stare Miasto Reservoir with moderate groundwater vulnerability risk zones were mainly located in the western part of the area and covered around 14\% of the studied area. The low groundwater vulnerability risk area covered about $9 \%$ of studied catchment in the southern part.

\section{Assessing Aquifer Vulnerability with the Modified DRASTIC Method}

To modify the original DRASTIC method, a parameter describing land use was added to the assessment and thus shallow groundwater vulnerability in the direct catchment of Stare Miasto reservoir was reevaluated. The modified-DRASTIC vulnerability map of the catchment was prepared using overlay analyses of the depth to water, net recharge, aquifer media, soil media, topography, impact of vadose zone, hydraulic conductivity, and land use. The calculated DI for the modified-DRASTIC method is between 40 and 88 (Fig. 3b). The results of the analysis show that $0.3 \%$ of the area is of very high vulnerability, $73.0 \%$ high vulnerability, $24.7 \%$ moderate vulnerability, and $2 \%$ low vulnerability. The risk map indicates that the moderate vulnerability area has increased by about $11 \%$ when compared to that according to the original DRASTIC map. 
a)

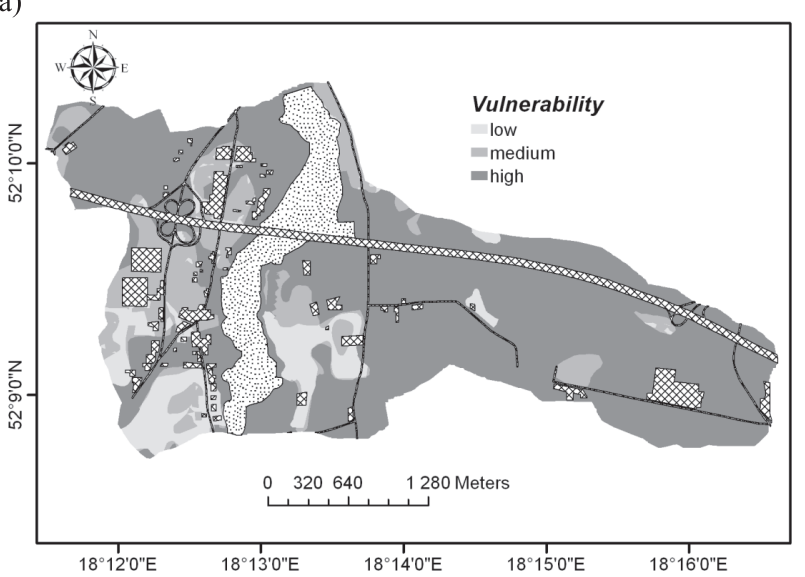

b)

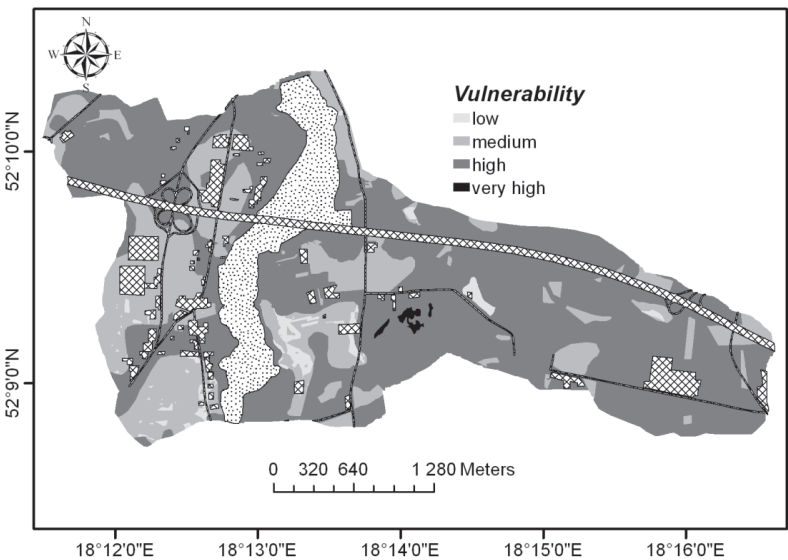

Fig. 3. Original a) and modified b) DRASTIC groundwater vulnerability maps.

A comparison of the modified DRASTIC vulnerability map with that from the original DRASTIC model revealed differences in $22 \%$ of the area. The risk map indicates that the low vulnerability area decreased from $8.6 \%$ (original method) to $2.0 \%$ (modified method), whereas the moderate vulnerability area increased from $14.0 \%$ to $24.7 \%$. The area characterised by high vulnerability to pollution decreased by $4 \%$ when compared to that predicted by the original DRASTIC map.

\section{Single-Parameter Sensitivity Analysis}

The single parameter sensitivity analysis compares effective weights with theoretical weights [27]. The effective weight is a function of the value of a single parameter with regard to the values of the other parameters as well as the weight assigned to them by the DRASTIC model. The effective weights of the DRASTIC parameters exhibited some deviation from the theoretical weights. Table 2 presents a statistical summary of the values of parameters of the original and modified DRASTIC methods. In the original DRASTIC model, the depth-to-groundwater table tends to be the most effective parameter in the vulnerability assessment with an average weight of $29.3 \%$ against the theoretical weight $(21.7 \%)$. The vadose zone also has high impact on the vulnerability assessment $(20.9 \%)$, but this layer is characterised by a lower effective weight than the theoretical one $(21.7 \%)$. Similarly, the calculated weights of the net recharge and hydraulic conductivity $(13.8 \%$ and $6.1 \%$, respectively) do not exceed the theoretical values $(17.4 \%$ and $13.0 \%$, respectively). The calculated weights of the aquifer media, soil media, and topography $(13.6 \%$, $10.4 \%$, and $5.9 \%$, respectively) exceed the theoretical ones $(13.0 \%, 8.7 \% \%$, and $4.3 \%$, respectively). In the modified DRASTIC method, the average effective weights of the impact of depth-to-groundwater table, net recharge, aquifer media, soil media, topography, vadose zone, and hydraulic conductivity parameters were calculated as $23.8 \%, 11.3 \%, 11.1 \%, 8.5 \%, 4.8 \%$, $17.2 \%$, and $5.1 \%$, respectively. As shown by the singleparameter sensitivity analysis, the land-use parameter has a high effective weight (18.3\%) in the aquifer vulnerability map.

Table 2. Statistics of single-parameter sensitivity analysis.

\begin{tabular}{|c|c|c|c|c|c|c|c|c|c|c|c|c|}
\hline \multirow{3}{*}{$\begin{array}{c}\text { Parameter } \\
\text { D }\end{array}$} & \multirow{2}{*}{\multicolumn{2}{|c|}{$\begin{array}{l}\text { Theoretical } \\
\text { weighting }\end{array}$}} & \multirow{2}{*}{\multicolumn{2}{|c|}{$\begin{array}{l}\text { Theoretical weighting } \\
\text { (\%) }\end{array}$}} & \multicolumn{8}{|c|}{ Effective weighting (\%) } \\
\hline & & & & & \multicolumn{2}{|c|}{ Minimum } & \multicolumn{2}{|c|}{ Maximum } & \multicolumn{2}{|c|}{ Mean } & \multicolumn{2}{|c|}{ SD } \\
\hline & 5 & $5 *$ & 21.7 & $17.9 *$ & 25.4 & $20.2^{*}$ & 45.9 & $37.9 *$ & 29.3 & $23.8^{*}$ & 4.6 & $3.0^{*}$ \\
\hline $\mathrm{R}$ & 4 & $4^{*}$ & 17.4 & $14.3 *$ & 6.6 & $5.8^{*}$ & 20.7 & $17.1 *$ & 13.8 & $11.3^{*}$ & 3.2 & $2.5^{*}$ \\
\hline A & 3 & $3 *$ & 13.0 & $10.7 *$ & 9.4 & $7.5^{*}$ & 19.4 & $15.2^{*}$ & 13.6 & $11.1^{*}$ & 1.4 & $1.5^{*}$ \\
\hline S & 2 & $2 *$ & 8.7 & $7.1^{*}$ & 7.2 & $5.7 *$ & 15.3 & $12.4 *$ & 10.4 & $8.5^{*}$ & 1.7 & $1.4^{*}$ \\
\hline $\mathrm{T}$ & 1 & $1 *$ & 4.4 & $3.5^{*}$ & 0.5 & $0.4^{*}$ & 8.8 & $7.8^{*}$ & 5.9 & $4.8^{*}$ & 1.7 & $1.3^{*}$ \\
\hline I & 5 & $5 *$ & 21.8 & $17.9 *$ & 10.5 & $8.1 *$ & 28.1 & $25.3 *$ & 20.9 & $17.2^{*}$ & 5.7 & $5.2 *$ \\
\hline $\mathrm{C}$ & 3 & $3 *$ & 13.0 & $10.7^{*}$ & 1.8 & $1.5^{*}$ & 16.5 & $14.5^{*}$ & 6.1 & $5.1 *$ & 2.8 & $2.4^{*}$ \\
\hline L & - & $5^{*}$ & - & $17.9 *$ & - & $7.1^{*}$ & 45.9 & $30.7 *$ & - & $18.3^{*}$ & - & $5.1^{*}$ \\
\hline
\end{tabular}

\footnotetext{
*values for modified DRASTIC
} 


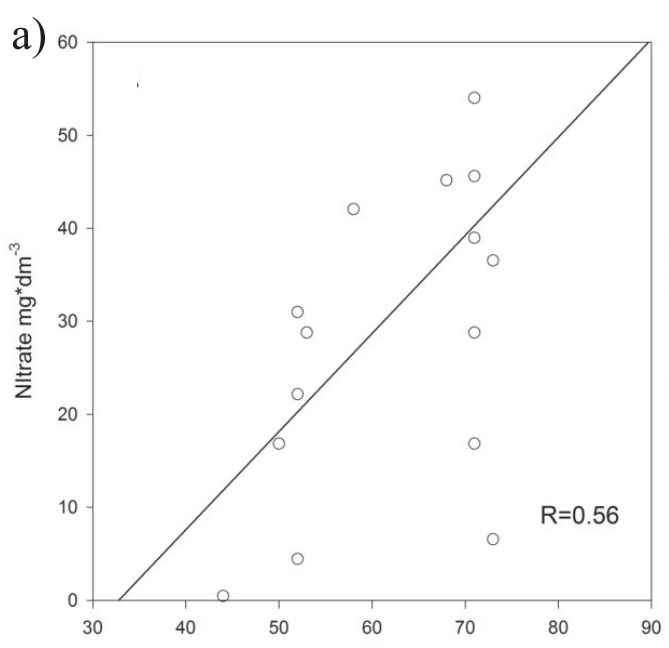

b)

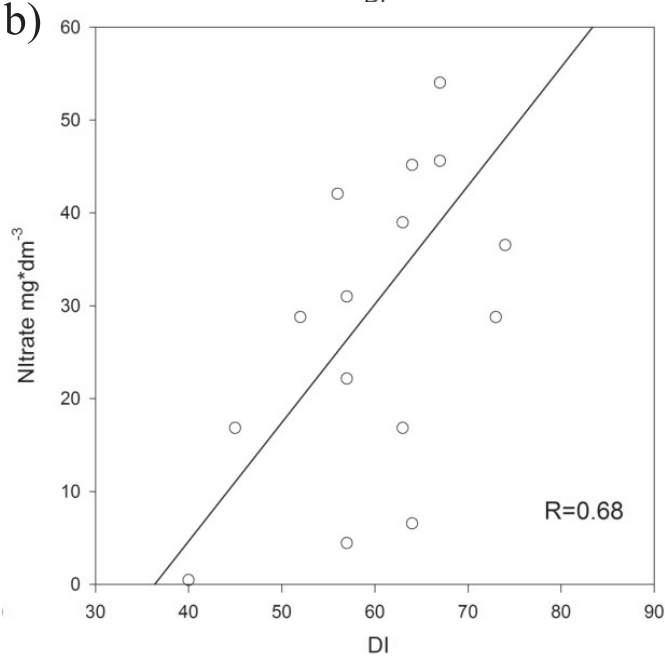

Fig. 4. Relationship between nitrate concentration and DI values: a) original DRASTIC method, b) modified DRASTIC method.

\section{Validating the Vulnerability Maps}

The nitrate concentration in shallow groundwater was tested and analysed at 17 different locations. The nitrate concentrations in groundwater were determined by a spectopotometric method. The measured nitrate concentrations were used to associate and correlate the pollution in the groundwater to the DRASTIC index obtained with the original and modified methods. Pearson's correlation factor was 0.56 in the original DRASTIC method, whereas in the modified model it was 0.69 (Fig. 4). This demonstrates that the vulnerability map prepared using the modified DRASTIC method is more accurate than that predicted by the original method.

\section{Conclusions}

In this study, the DRASTIC method working in the GIS environment was used to determining the vulnerability of the shallow groundwater in the direct catchment of Stare Miasto Reservoir. Although very successful in some case studies, the DRASTIC method has some drawbacks. The influence of local characteristics (geology, hydrology, hydrogeology, etc.) is not accounted for in the method and the same weights and rating values are used. Therefore, it is necessary to modify the original algorithm in order to obtain results that are more accurate. In this study, the DRASTIC method was modified by adding a parameter describing the type of land use. Land use is one of the important parameters reflecting anthropogenic impact. The calculated DRASTIC vulnerability index (normalized) for the modified DRASTIC map is between 40 and 88 . The aquifer vulnerability map shows the dominance of high vulnerability class in the eastern and northwestern parts of the direct catchment analysed.

The effects of the DRASTIC methods on the vulnerability maps were investigated using a singleparameter sensitivity analysis. According to the results of this analysis, depth-to-groundwater and land-use parameters have the highest effective weights when compared to those of the other parameters. In addition, the measured nitrate concentrations were compared and used for correlating the pollution in the groundwater to the aquifer vulnerability maps that were prepared using different methods. Generally, nitrate concentrations in shallow groundwater from the areas that are classified as highly vulnerable were high. Furthermore, Pearson's correlation factor was calculated to determine the statistical relationship between the nitrate concentration in the groundwater and the aquifer vulnerability maps. The correlation factor between the nitrate concentrations and the original vulnerability index was evaluated at 0.56 , whereas the correlation factor between the nitrate concentrations and the modified DRASTIC model was calculated at 0.69 . These results indicate that the modified DRASTIC method could provide more reliable results as compared with the original DRASTIC model.

This study provides a valuable tool for policy makers responsible for planning the development in a given area in the form of maps showing vulnerability to shallow groundwater and surface water contamination. The groundwater vulnerability maps of the direct catchment of the Stare Miasto Reservoir are ideal for use in future land-use planning. Regarding urban planning and the organization of agricultural activities in the Stare Miasto districts, the vulnerability risk map prepared in the study could be the most important when considering protection of groundwater quality. In areas with high and very high vulnerability to groundwater pollution, there should be restrictions on soil fertilization as well as permanent pasture, or afforestation should be introduced in the arable land. In addition, these areas should not be converted into housing developments. 


\section{Acknowledgements}

This work is part of a scientific grant, "Initial sedimentation part in small lowland reservoirs: modelling and analysis of functionality," funded by the National Science Centre in Poland as project No. N N305 296740.

\section{Conflict of Interest}

The authors declare no conflict of interest

\section{References}

1. FRANKOWSKI M., SOJKA M., ZIOŁA-FRANKOWSKA A., SIEPAK M., MURAT-BŁAŻEJEWSKA S. Distribution of heavy metals in the Mala Welna River system (western Poland). Oceanological and Hydrobiological Studies, 38 (2), 51, 2009.

2. KOZŁOWSKI M., KOMISAREK J. Temporal variability of selected dissolved components content in groundwater of the catena system of Poznan Lakeland. Annual Set The Environment Protection, 15, 1965, 2013.

3. KOZŁOWSKI M., KOMISAREK J. Groundwater chemistry and hydrogeochemical processes in a soil catena of the Poznan Lakeland, central Poland. Journal of Elementology, 22 (2), 681, 2017.

4. SIEPAK M., SOJKA M. Application of multivariate statistical approach to identify trace elements sources in surface waters: a case study of Kowalskie and Stare Miasto reservoirs, Poland. Environmental Monitoring and Assessment, 189 (8), 364, 2017.

5. PRZYBYŁA C., KOZDRÓJ P., SOJKA M. Application of Multivariate Statistical Methods in Water Quality Assessment of River-reservoirs Systems (on the Example of Jutrosin and Pakosław Reservoirs, Orla Basin). Annual Set The Environment Protection, 17 (2), 1125, 2015.

6. PTAK M., ŁAWNICZAK A.E. Changes in land use in the buffer zone of lake of the Mała Wełna catchment, Limnological Review, 12 (1), 35, 2012.

7. ALLER L., BENNETT T., LEHR J.H., PETTY R.J., HACKETT G. DRASTIC: a standardized system to evaluating ground water pollution potential using hydrogeological settings. U.S. EPA Report 600/2 - 85/018, 62, 1987.

8. TILAHUN K., MERKEL B.J. Assessment of groundwater vulnerability to pollution in Dire Dawa, Ethiopia using DRASTIC. Environmental Earth Sciences, 59 (7), 1485, 2010.

9. NESHAT A., PRADHAN B., PIRASTEH S., SHAFRI H.Z.M. Estimating groundwater vulnerability to pollution using a modified DRASTIC model in the Kerman agricultural area, Iran. Environmental Earth Sciences, 71 (7), 3119, 2014.

10. AKHAVAN S., MOUSAVI S.F., ABEDI-KOUPAI J., ABBASPOUR K.C. Conditioning DRASTIC model to simulate nitrate pollution case study: HamadanBahar plain. Environmental Earth Sciences, 63 (6), 1155, 2011.

11. YANG J., TANG Z.H., JIAO T., MUHAMMAD A.M. Combining AHP and genetic algorithms approaches to modify DRASTIC model to assess groundwater vulnerability: a case study from Jianghan Plain, China. Environmental Earth Sciences, 76 (12), 426, 2017.

12. ASSAF H., SAADEH M. Geostatistical assessment of groundwater nitrate contamination with reflection on DRASTIC vulnerability assessment: The case of the Upper Litani Basin, Lebanon. Water Resources Management, 23 (4), 775, 2009.

13. ANTONAKOS A.K., LAMBRAKIS N.J. Development and testing of three hybrid methods for the assessment of aquifer vulnerability to nitrates, based on the drastic model, an example from NE Korinthia, Greece. Journal of Hydrology, 333 (2), 288, 2007.

14. MIMI Z.A., MAHMOUD N., MADI M.A. Modified DRASTIC assessment for intrinsic vulnerability mapping of karst aquifers: a case study. Environmental Earth Sciences, 66 (2), 447, 2012.

15. LEONE A., RIPA M.N., URICCHIO V., DEÁK J., VARGAY Z. Vulnerability and risk evaluation of agricultural nitrogen pollution for Hungary's main aquifer using DRASTIC and GLEAMS models. Journal of Environmental Management, 90 (10), 2969, 2009.

16. ANANE M., ABIDI B., LACHAAL F., LIMAM A., JELLALI S. GIS-based DRASTIC, Pesticide DRASTIC and the Susceptibility Index (SI): comparative study for evaluation of pollution potential in the Nabeul-Hammamet shallow aquifer, Tunisia. Hydrogeology Journal, 21 (3), 715, 2013.

17. PRASAD R.K., SINGH V.S., KRISHNAMACHARYULU S.K.G., BANERJEE P. Application of drastic model and GIS: for assessing vulnerability in hard rock granitic aquifer. Environmental Monitoring and Assessment, 176 (1-4), 143, 2011.

18. LIMA M.L., ZELAYA K., MASSONE H. Groundwater vulnerability assessment combining the drastic and DynaClue Model in the Argentine pampas. Environmental Management, 47 (5), 828, 2011.

19. SHIRAZI S.M., IMRAN H.M., AKIB S., YUSOP Z., HARUN Z.B. Groundwater vulnerability assessment in the Melaka State of Malaysia using DRASTIC and GIS techniques. Environmental Earth Sciences, 70 (5), 2293, 2013.

20. KUMAR S., THIRUMALAIVASAN D. RADHAKRISHNAN N. GIS Based Assessment of Groundwater Vulnerability Using DRASTIC Model. Arabian Journal for Science and Engineering, 39 (1), 207, 2014.

21. SENER E., SENER S., DAVRAZ A. Assessment of aquifer vulnerability based on GIS and DRASTIC methods: a case study of the Senirkent-Uluborlu Basin (Isparta, Turkey). Hydrogeology Journal, 17 (8), 2023, 2009.

22. HUAN H., WANG J., TENG Y. Assessment and validation of groundwater vulnerability to nitrate based on a modified DRASTIC model: A case study in Jilin City of northeast China. Science of the Total Environment, 440, 14, 2012.

23. HERLINGER JR R., VIERO A.P. Groundwater vulnerability assessment in coastal plain of Rio Grande do Sul State, Brazil, using DRASTIC and adsorption capacity of soils. Environmental Geology, 52 (5), 819, 2007.

24. WU W., YIN S., LIU H., CHEN H. Groundwater Vulnerability Assessment and Feasibility Mapping Under Reclaimed Water Irrigation by a Modified DRASTIC Model. Water Resources Management, 28 (5), 1219, 2014.

25. PACHECO F.A., SANCHES-FERNANDES L.F. The multivariate statistical structure of DRASTIC model. Journal of Hydrology, 476, 442, 2013. 
26. SAHOO S., DHAR A., KAR A., CHAKRABORTY D. Index-based groundwater vulnerability mapping using quantitative parameters. Environmental Earth Sciences, 75, 522, 2016.

27. BABIKER I.S., MOHAMED M.A., HIYAMA T., KATO K. A GIS-based DRASTIC model for assessing aquifer vulnerability in Kakamigahara Heights, Gifu Prefecture, central Japan. Science of the Total Environment, 345 (1), 127, 2005.

28. PATHAK D.R., HIRATSUKA A., AWATA I., CHEN L. Groundwater vulnerability assessment in shallow aquifer of Kathmandu Valley using GIS-based DRASTIC model. Environmental Geology, 57 (7), 1569, 2009.

29. SHRESTHA S., SEMKUYU D.J., PANDEY V.P. Assessment of groundwater vulnerability and risk to pollution in Kathmandu Valley, Nepal. Science of The Total Environment, 556, 23, 2016.

30. SINAN M., RAZACK M. An extension to the DRASTIC model to assess groundwater vulnerability to pollution: application to the Haouz aquifer of Marrakech (Morocco). Environmental Geology, 57 (2), 349, 2009.

31. SENER E., SENER S., DAVRAZ A. Assessment of aquifer vulnerability based on GIS and DRASTIC methods: a case study of the Senirkent-Uluborlu Basin (Isparta, Turkey). Hydrogeology Journal, 17 (8), 2023, 2009.
32. SENER E., DAVRAZ A. Assessment of groundwater vulnerability based on a modified DRASTIC model, GIS and an analytic hierarchy process (AHP) method: the case of Egirdir Lake basin (Isparta, Turkey). Hydrogeology Journal, 21 (3), 701, 2013.

33. KIHUMBA A.M., VANCLOOSTER M., LONGO J.N. Assessing groundwater vulnerability in the Kinshasa region, DR Congo, using a calibrated DRASTIC model. Journal of African Earth Sciences, 126, 13, 2017.

34. SOJKA M., SIEPAK M., GNOJSKA E. Assessment of Heavy Metal Concentration in Bottom Sediments of Stare Miasto Pre-dam Reservoir on the Powa River. Annual Set the Environment Protection, 15, 1916, 2013.

35. BATELAAN O., DE SMEDT F. GIS based recharge estimation by coupling surface-subsurface water balances. Journal of Hydrology, 337 (3-4), 337, 2007.

36. PAZDRO Z., KOZERSKI B. General Hydrogeology. WG Press Warszawa 5241990 [In Polish]

37. DOMENICO P.A., SCHWARTZ F.W. Physical and Chemical Hydrogeology. John Wiley \& Sons, Inc., New York, NY, 1990.

38. SCHAAP M.G., LEIJ F.J., VAN GENUCHTEN M.T. ROSETTA: a computer program for estimating soil hydraulic parameters with hierarchical pedotransfer functions. Journal of Hydrology, 251, 163, 2001. 
